\title{
DOE Request for
} Information (RFI)

DE-FOA-0000153 PV

Manufacturing Initiative

February 2010

\section{Summary Report}




\section{DOE Request for Information (RFI) DE-FOA-0000153 PV Manufacturing Initiative}

\section{Summary Report}

DATE: February 2010

FROM: DOE Solar Energy Technologies Program

TO: $\quad$ Public Release and Distribution 


\section{TABLE OF CONTENTS}

SECTION TITLE

PAGE

I.

Summary

2

II.

RFI Response Themes

2

ATTACHMENTS

Attachment 1 PV Manufacturing Initiative RFI 


\section{Summary}

Last year, the U.S. Department of Energy (DOE) Solar Energy Technologies Program began exploring concepts for a "PV Manufacturing Initiative" to facilitate the development of a strong photovoltaic (PV) manufacturing industry in the United States. As an integral part this effort, and to inform the creation of a new funding opportunity in this area, DOE sought feedback from the PV industry.

This document summarizes the results of the PV Manufacturing Request for Information (RFI), DE-FOA-0000153. (See Attachment 1.) The RFI was posted on http://www.grants.gov on 4 September 2009 and the NREL Web site on 9 September 2009. Respondents were asked to submit RFI inputs to PVManuflnit@go.doe.gov by 30 September 2009. A total of 58 responses were received. The 58 responses consisted of 30 Industry, 11 University, 11 Consortia, 2 National Lab, and 5 noncompliant inputs. ${ }^{1}$ The responding organizations and their contact information are provided in Attachment 2.

This document summarizes the inputs as a set of common themes from the responses. The specific answers, recommendations, and suggested approaches from each respondent were also captured and individually summarized, but are not included in this document because they are identified with specific respondents.

\section{RFI Response Themes:}

Based on a review of the submitted responses there were several themes and observations that ran throughout. They are summarized as follows:

1) The existence of local markets is very important to the development of U.S.-based PV manufacturing. Preparing the domestic manufacturing base for increased productivity via the PV Manufacturing Initiative may have little impact without increased demand for PV systems in the United States. Several respondents recommended stimulating market demand through feed-in-tariffs, investment tax credits, and various taxes that inflate the relative cost of traditional energy sources as a complementary approach to the PV Manufacturing Initiative.

2) The respondents were broadly supportive of the establishment of this program as a way to increase U.S.-based PV manufacturing.

3) In general, industry responses advocated Industry-led consortia, universities advocated University-led consortia, and equipment manufacturers were proponents of Manufacturing Development Facilities (MDFs). Similarly, thin-film manufacturers recommended a focus on thin-film technologies because they have the highest future potential and the United States has a lead in thin-films, whereas silicon manufacturers preferred a focus on their technologies due to the dominant position of crystalline silicon (c-Si) in the industry.

4) Several respondents requested a clearer statement of the goals and objectives of the initiative, especially for the Industry-led consortia. Such a statement might include a description of the technologies, barriers, and/or stages of commercialization the initiative is intended to address.

5) There was approximately equal support for Industry-led consortia and MDFs as good models, with a few responses advocating a combined or hybrid industry consortia / MDF

\footnotetext{
${ }^{1}$ Non-compliant responses did not address the questions posed in the RFI, nor any of the concepts or merits of the PV Manufacturing Initiative more generally. They typically contained only background or promotional information on the responding company.
} 
model, stating that manufacturing process and equipment development was integral to success for both models.

6) Some industry respondents expressed concern that University-led consortia might not be responsive to industry and manufacturers' needs, or timely in their response. Several respondents referred to the disparity between the goals and time constraints of universities and of industry, and to the need to proactively address the issue. The proposed approaches were for Industry-led consortia to include universities, or if University-led consortia are chosen, to require strong industry advisers, participation, and oversight.

7) The role of universities in producing a well-trained, domestic PV workforce was emphasized.

8) Different $\mathrm{PV}$ technologies, and technologies at different stages of development, may be best suited to different consortia models.

9) In general, intellectual property (IP) issues were perceived as the most difficult barrier to overcome. Industry / for-profit entities were perceived as being at a disadvantage in this respect due to self-interest overwhelming the process. Universities and MDFs were thought to be less competitive entities for IP rights and better positioned to address the IP issue. Suggested methods to approach the IP issue included funding only precompetitive research or focusing on module issues common throughout the industry.

10) The approach to IP within a consortium or facility should be clearly resolved and documented in the proposal, at the outset. Alternate approaches should be allowed, such as a "pool and draft" model, terms that allow for exclusivity under certain conditions, etc.

11) Handling of IP ownership among different companies may be simpler when they hold non-overlapping positions in the value chain.

12) Sharing of IP may lead to a watering down of results, in that companies with the most innovative approaches may not participate. The result would be projects funded for the least interesting technologies.

13) Small companies, in particular, are reliant upon retaining the rights to their IP and may be reluctant to join Industry-led consortia requiring IP sharing. Collaborations with universities may be more appealing to start-up companies.

14) In any model, member access to industrial scale equipment and expertise is vital, with pilot lines being important to proving commercial and manufacturing viability. Metrology, testing, and benchmarking capabilities were also noted as important. Funds may need to be allocated for investment in capital equipment.

15) Some respondents suggested that any RFP should include guidelines on how to specify project goals, milestones, and management methods within the consortium or facility. These management specifications might include the role of the consortium leader, timelines for pilot-scale and/or volume manufacturing of new technologies, and technology transfer plans for university participants.

16) Multiple respondents indicated that $P V$ standards development may occur naturally within the consortium framework, without suggesting that such development be a requirement for a successful consortium. There was a favorable stance on the importance of standards development at this point in the industry's maturity, though opinion was not uniform. 
17) Overall the respondents favored fewer awards with higher funding so the awardees can reach critical mass for impacting the industry, though some advocated a balance between larger and smaller awards. Additionally, the point was made several times that $\mathrm{PV}$ manufacturing is capital intensive and so the proposed funding may not be adequate. The funding falloff over three years for MDFs may be too fast considering the time and capital expenditures required to become self-sustaining.

18) Respondents mostly favored having no restriction on the number of consortium participants, preferring to let the needs and goals of the proposed consortium dictate appropriate size.

19) Two respondents indicated the Technology Pathway Partnership (TPP) program was an example of a successful Industry-led consortia program. SEMATECH was also suggested as an Industry-led consortium model. A few mentioned the NREL Thin-Film Partnership program as a model of success. Several specific centers for collaboration, IP sharing, and tech transfer between universities and companies were also named as successful models.

20) Several respondents recommended the PV industry supply chain to be modeled like that of the semiconductor industry.

21) Universities tended to report that a $20 \%$ cost share was prohibitive and/or difficult to meet. Some stated that in-kind contributions of equipment or equipment time from industry partners needed to count toward the cost-share. Additionally, a few respondents suggested that the $50 \%$ cost-share percentage should be lower for small companies. 


\section{Attachment 1. PV Manufacturing Initiative RFI}

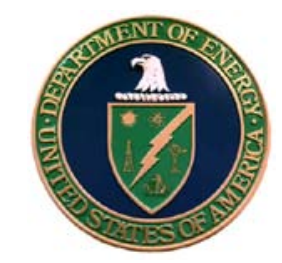

\section{DOE Request for Information (RFI) \\ DE-FOA-0000153}

\section{PV Manufacturing Initiative}

\section{Program Manager/Area}

JoAnn Milliken, Acting Program Manager, Solar Energy Technologies Program, Office of Energy Efficiency and Renewable Energy.

\section{Background and Rationale}

The mission of the Department of Energy's (DOE) Solar Energy Technologies Program (SETP) is to accelerate the wide-spread adoption of solar electric technologies across the United States through a program of applied research and development, demonstration, and market transformation activities. This mission aims to diversify the Nation's electricity supply options, increase national security, and improve the environment. The SETP mission is consistent with the Energy Policy Act of 2005 and DOE's Strategic Plan.

During the past decade, worldwide demand for and production of photovoltaic (PV) energy systems has been growing at a compound annual growth rate of more than $30 \%$. This growth has taken place in response to government support programs in Germany, Spain, and other countries outside the United States. Demand for PV products has the potential to also grow in the United States due to new and emerging Federal and State support programs and favorable solar conditions, as well as declining system costs. The United States, however, is not currently a major manufacturer of PV products, and therefore, not well-positioned to take advantage of this opportunity's potential to create a strong domestic industry.

The "PV Manufacturing Initiative" is intended to coordinate stakeholders and technology development efforts across the solar community to facilitate the development of a strong PV manufacturing industry in the United States. The primary goals of this initiative include supporting the creation of a robust United States-based PV manufacturing technology including infrastructure and supply chain base, developing a highly trained workforce with the critical skills required to meet the needs of a rapidly growing industry, and speeding the implementation of new cutting edge technologies.

Three separate models are currently under consideration: (1) university-led consortia guided by industry that would conduct industry-relevant manufacturing research projects; (2) collaborative industry-led consortia that will develop and implement manufacturing research projects with shared intellectual property (IP); and (3) manufacturing development efforts, possibly implemented through common facilities, for equipment and process development with individual companies maintaining exclusive ownership of IP. 


\section{Proposed Strategy}

This funding opportunity announcement (FOA) will enable DOE to launch a major PV Manufacturing Initiative that will accelerate development and provide a strong base for a domestic United States PV industry. DOE anticipates that up to $\$ 30 \mathrm{M}$ will be available to fund the PV Manufacturing Initiative in the first year. Of that, DOE anticipates that approximately $\$ 5 \mathrm{M}$ will be devoted to a single or multiple awards for University-Led Consortia. The remaining $\$ 25 \mathrm{M}$ may be used to fund single or multiple awards for Collaborative Industry-led Consortia and/or Manufacturing Development Facilities.

All proposals to implement Initiative models will be evaluated according to a competitive award process. In all cases, successful proposals will be expected to maximize the number of alternative funding sources, provide geographic diversity, incorporate a broad base of the PV industry, and have a detailed plan for the management of intellectual property, consortium membership (if a consortia is proposed), and other governance issues. All PV technologies (i.e., wafer, thin film, and concentrator) and combinations of technologies may be considered. The industry-led models (the collaborative industry consortia and manufacturing development facilities) are intended to allow the integration of universities and workforce development; likewise, the university led model should have strong ties to industry. All model approaches are also intended to allow for the technical participation of national laboratories, as defined in Section 2 of the Energy Policy Act of 2005. Regarding financial participation, each model encourages inclusion of state economic development or other funding organizations.

Entities who apply for multiple awards should be able to demonstrate that they can complete all the work proposed.

Below are characteristics of the three models being considered to implement the goals of the Initiative.

\section{University-Led Consortia:}

DOE would maintain a constant level of funding over the first 5 years for each UniversityLed Consortium, with the option to extend for 5 years either through an extension of the existing award, or as a subsequent competitive opportunity. Additional sources of funding would be expected by industry participants and universities. The consortia would select projects proposed by the universities in consultation with industry.

The specific problems to be addressed will be identified through rigorous planning and implementation of industry-relevant collaborative research plans. Based on the development opportunities identified, the consortia will fund development projects with the expectation of delivering new offerings to market within 2-5 years. Participation in standards or roadmap planning activities could be considered part of the scope of these consortia.

Successful consortia will provide interested graduate-level and post-doctoral students with opportunities for direct experience in research and development (R\&D) projects and hands-on training in industrially viable manufacturing processes. The consortia would also address how its relationship with the PV industry is expected to produce graduates from the university that have a thorough understanding of PVs from materials to systems, excellent proficiency in device, module and system aspects of PVs, and the technical communication skills that are highly valued by the industry. 


\section{Collaborative Industry-Led Consortia}

DOE support for each Collaborative Industry-Led Consortium would fund initial projects in combination with other funding sources, with the DOE share of support gradually decreasing over 5 years and industry and other parties assuming a greater share over that time span. Additionally, it is expected that all industry participants could equitably share in the intellectual property developed through each consortium.

The specific problems to be addressed will be identified through rigorous planning and implementation of industry relevant collaborative research plans. Based on the development opportunities identified, the consortia will fund development projects with the expectation of delivering new offerings to market within 2-5 years. Because of the anticipated membership of diverse companies across the PV industry, it may be desirable for these consortia to serve as a major resource and leading contributor to industry-wide standards and roadmap development.

\section{Manufacturing Development Facilities:}

DOE funding for Manufacturing Development Facilities would provide initial awards to set up the facilities, with additional funding for these facilities also expected to come through the organizing entity, user fees, equipment providers, and other participants. DOE funding would be gradually reduced over $1-3$ years with other participants assuming a greater share. Manufacturing Development Facility awards could be executed with an organization with ties to the PV industry, industry-led consortium, or as a separate entity. Either new or retooled manufacturing development facilities could be established. These facilities will assist potentially a wide-range of PV companies in making the transition to commercial production. In contrast to the Collaborative IndustryLed Consortia, intellectual property developed through these facilities will be owned by user companies.

Manufacturing Development Facilities could be implemented with some or all of the following characteristics: provide tools with common uses to innovate around and test processing parameters; facilitate matchmaking between process innovators and the development facilities of equipment manufacturers; enable users to access process development and characterization capabilities to aid benchmarking and troubleshooting manufacturing processes; and give users access to technical expertise and manufacturing equipment to speed development to full commercial manufacturing capability.

Participation in standards or roadmap planning activities could be considered part of the scope of work for the Manufacturing Development Facility awardees. 


\section{Award and Financial Information}

Total Estimated Cost of the Project: $\$ 125,000,000$ - $\$ 200,000,000$ (DOE and Cost share) depending on mix of models selected.

Total DOE Funding Anticipated: \$100,000,000

Initial Funding: $\$ 30,000,000$

Anticipated level of required cost share:

University Led Collaborative Consortia, 20\%

Collaborative Industry Led Consortia, 50\%

Manufacturing Development Facilities, 50\%

Fiscal Year of Initial Funding: FY10

\section{Estimated Project Period of Awards:}

University-Led Consortia, 5 years

Collaborative Industry-Led Consortia, 5 years

Manufacturing Development Facilities, 1-3 years

Qualifications or Restricted Eligibility:

The University-Led consortia is restricted to domestic universities. Industry participants for the Collaborative Industry-Led Consortia must have United States-based PV research facilities and demonstrated intent for United States manufacturing within 3 years. All other participants must be United States-based organizations.

\section{DOE Laboratory Involvement:}

National laboratories may not apply as prime applicants but may apply as team members. 


\section{Request for Information Guidelines}

Respondents are asked to specifically comment on the questions below. Respondents are also encouraged to comment on the general concept, potential benefits or obstacles, the overall merits of this idea, alternatives, and the relative priority of this activity. DOE will evaluate responses to this RFI to determine the best approach to move forward.

\section{Questions}

1) Concept:

- Please comment on the three models comprising the PV Manufacturing Initiative. How well is the problem framed, and are the models identified correct possible solutions? Will the models identified accomplish the goals of the Initiative? Are there other, more expedient approaches to achieving the goals? Should the models be modified? Do any of the models have higher priority? Are there other models that have been left out that should also be considered?

-What PV technologies would most likely succeed using these or other models?

- What are the most likely organizational barriers that may arise (e.g. IP sharing issues), and are there solutions DOE should consider?

\section{2) Benefits:}

- What do you see as the greatest contributions the PV Manufacturing Initiative can make to establish a strong manufacturing base and supply chain for the United States PV industry?

\section{3) Eligibility}

- Do you agree with the eligibility for the leads and participants for the University-Led Consortia? What about the Collaborative Industry-Led Consortia? And the Manufacturing Development Facilities?

- Should "for profit" consortia be considered or only non-profit entities?

- Should there be a minimum number of partners required by DOE for award or could a consortium be contained within one institution with far-reaching activity?

4) Funding:

- Would it be better to fund more awards at lower levels or fewer awards at higher levels?

- Does the level of funding seem appropriate given the amount and type of work anticipated?

- Does the level of cost share seem appropriate?

DOE will not pay for information provided under this Request for Information (RFI), and there is no guarantee that a project will be supported as a result of this RFI. This RFI is not accepting applications for financial assistance or financial incentives.

A response to this RFI will not be viewed as a binding commitment to develop or pursue the project or ideas discussed. DOE may also decide at a later date to issue Funding Opportunity Announcements (FOAs), based on consideration of the input received from this RFI or to not issue this opportunity at all. 
Respondents are requested to provide the following information at the start of their response to this $\mathrm{RFI}$ :

- Company/institutional name,

- Company/institutional contact,

- Type of Business or Institution

- Address, phone number, and e-mail address

- Brief description of the operations and mission of business or institution (several sentences will suffice)

All responses to this RFI must be delivered electronically in Microsoft Word (.doc) format as an attachment to an email sent to the following email address: PVManufInit@go.doe.gov. Emails should have the subject line "PV Manufacturing Initiative Response".

Any questions about the content of this RFI must be sent to the following email address: PVManuflnit@go.doe.gov. Emails should have the subject line "Question”.

Responses to this RFI must be submitted by 11:59 PM Eastern Time on September 30, 2009.

Responses should be limited to 5 pages. However, more than one response is allowed per respondent. Please identify your answers by responding to a specific question if possible. We welcome other comments as well. Identifying the comment with the item to which it refers will facilitate aggregating all the responses. Any information obtained as a result of this RFI is intended to be used by the Government on a non-attribution basis for program planning and procurement strategy development. Information or data that is restricted in any way or limited for use by the Government is not solicited and will not be considered. Please do not respond with any information you deem proprietary or confidential. Responses to this RFI are not confidential and may be published publically on a non-attribution basis.

DOE has no obligation to respond to those who submit comments, and/or give any feedback on any decision made based on the comments received, as there is potential for a future Funding Opportunity relative to this subject.

DOE thanks you for your assistance and comments in helping accomplish its mission. 


\section{Attachment 2. Responding Organizations and Contact Information}

\begin{tabular}{|c|c|c|c|c|c|c|c|c|}
\hline \multicolumn{9}{|c|}{ Industry Respondent Contact Information } \\
\hline Respondent & Contact & Contact Title & Street Address & City & State & Zip & Phone Number & Email \\
\hline 1Soltech & Zak Fardi & Executive V.P. & $\begin{array}{l}671 \text { North Plano Rd, } \\
\text { Suite \#202 }\end{array}$ & Richardson & $\mathrm{TX}$ & 75081 & $972-231-1158$ & Zak.fardi@1soltech.com \\
\hline \multirow{2}{*}{ Abound Solar } & Anders Olsson & SVP of R \& D & - & - & - & - & $970-619-5340$ & aolsson@abound.com \\
\hline & alt: Doug Schatz, CEO & & - & - & - & - & & \\
\hline Applied Materials & Nag Patibandla, Ph.D. & Director, External Programs & \begin{tabular}{|l|}
3225 Oakmead \\
Village Dr, P.O. Box \\
58039, M/S 1240
\end{tabular} & Santa Clara & $\mathrm{CA}$ & 95052 & $408-563-5224$ & nag_patibandla@amat.com \\
\hline BandGap Engineering & Chris Hobson & Chief Operating Officer & 1344 Main Street & Waltham & MA & 02451 & - & - \\
\hline BASF Corp & Dr. Timea Marsalko & - & 1609 Biddle Ave & Wyandotte & $\mathrm{MI}$ & 48192 & $734-324-6692$ & timea.marsalko@basf.com \\
\hline BP Solar & John Wohlgemuth & & 630 Solarex Court & Frederick & $\mathrm{MD}$ & 21703 & $301-698-4375$ & \\
\hline \multirow{2}{*}{ CH2M Hill } & Michael O'Halloran & - & 2020 SW 4th Ave & Portland & OR & 97201 & $503-224-6040$ & michael.ohalloran@ch2m.com \\
\hline & Nathan Monosoff & - & 2020 SW 4th Ave & Portland & OR & 97201 & $503-224-6040$ & nathan.monosoff@ch2m.com \\
\hline Cimitrex & Dave Faulkner & Executive VP & \begin{tabular}{|l|}
6979 South High \\
Tech Drive \\
\end{tabular} & Salt Lake City & UT & 84047 & - & dave.faulkner@cimetrix.com \\
\hline Dupont & Jeffrey Sternberg & Research Manager & $\begin{array}{l}\text { Experimental } \\
\text { Station, E500/2210A } \\
\text { P.O. Box } 80500\end{array}$ & Wilmington & $\mathrm{DE}$ & $19880-0500$ & $302-685-4309$ & $\begin{array}{l}\text { jeffrey.a.sternberg@usa.dupont.co } \\
m\end{array}$ \\
\hline EcoPower Design & Ken Scott & CEO & $\begin{array}{l}830 \text { Stewart Drive } \\
\text { Suite } 222\end{array}$ & Sunnyvale & $\mathrm{CA}$ & 94085 & $408-457-7966$ & kscott@ecopowerdesign.com \\
\hline GT Solar & David C. Gray & VP of Strategic Development & $\begin{array}{l}243 \text { Daniel Webster } \\
\text { Highway }\end{array}$ & Merrimack & $\mathrm{NH}$ & 03054 & $603-681-3825$ & David.Gray@GTsolar.com \\
\hline Heliovolt & Dr. B.J. Stanbery & - & $\begin{array}{l}6301 \text { E Stassney } \\
\text { Lane, Bldg } 8, \text { Ste } \\
100\end{array}$ & Austin & TX & 78744-1604 & $512-767-6067$ & - \\
\hline Intermolecular & Craig Hunter & - & 2865 Zanker Road & San Jose & $\mathrm{CA}$ & 95134 & $408-416-2300$ & chunter@intermolecular.com \\
\hline Micron Technologies & John Maculley & - & $\begin{array}{l}8000 \text { S. Federal } \\
\text { Way, MS-36-206T }\end{array}$ & Boise & ID & 83707 & $208-363-5218$ & jmaculley@micron.com \\
\hline MidWest Curtain Walls & Mr. Donald F. Kelly, Jr. & President & 5171 Grant Avenue & Cleveland & $\mathrm{OH}$ & 44126 & $216-641-9053$ & dfk@midwestcurtainwalls.com \\
\hline NAVSEMI & Babu Jain & - & $\begin{array}{l}5205 \text { Prospect Rd, } \\
\# 135-127\end{array}$ & San Jose & $\mathrm{CA}$ & 95129 & $408-465-5521$ & Babu.jain@navsemi.com \\
\hline nScrypt & Rebecca Couchon & Business Contact & $\begin{array}{l}3251 \text { Progress Drive, } \\
\text { Suite D }\end{array}$ & Orlando & $\mathrm{FL}$ & 32856 & $407-275-4720$ & rcouchon@nscryptinc.com \\
\hline & alt: Kenneth Church & Technical Contact & & & & & & kchurch@nscryptinc.com \\
\hline
\end{tabular}




\begin{tabular}{|c|c|c|c|c|c|c|c|c|}
\hline \multicolumn{9}{|c|}{ Industry Respondent Contact Information (cont.) } \\
\hline Respondent & Contact & Contact Title & Street Address & City & State & Zip & Phone Number & Email \\
\hline Plextronics & James Dietz & $\begin{array}{l}\text { Vice President of Business } \\
\text { Development }\end{array}$ & $\begin{array}{l}2180 \text { William Pitt } \\
\text { Way }\end{array}$ & Pittsburgh & PA & 15238 & $\begin{array}{c}412-423-2030 \text { ext. } \\
103\end{array}$ & jdietz@plextronics.com \\
\hline RNY Solar & Jim Munro & СTO & $\begin{array}{l}4567 \text { Ontario Center } \\
\text { Road }\end{array}$ & Walworth & NY & 14568 & $585-503-5180$ & jfmunro@rnysolar.com \\
\hline Semprius & Bob Conner & VP, Photovoltaics & \begin{tabular}{|l|}
4915 Prospectus \\
Drive, Suite C
\end{tabular} & Durham & $\mathrm{NC}$ & 27713 & $919-757-6825$ & bob.conner@semprius.com \\
\hline Solaicx & Peter V. Schwartz, Ph.D. & Vice President of Engineering & 5102 Calle del Sol & Santa Clara & CA & 95054 & $408-988-5000$ & pschwartz@solaicx.com \\
\hline Solarma & Vishal Shrotriya, Ph.D. & $\begin{array}{l}\text { Director, Business } \\
\text { Development }\end{array}$ & $\begin{array}{l}3445 \text { Fletcher } \\
\text { Avenue }\end{array}$ & El Monte & $\mathrm{CA}$ & 91731 & $\begin{array}{c}626-456-8090 \text { ext. } \\
312 \\
\end{array}$ & vishals@solarmer.com \\
\hline Solar World & Dr. James A. Moreland & Vice President of Technology & $\begin{array}{l}25300 \text { Evergreen } \\
\text { Road }\end{array}$ & Hillsboro & OR & 97124 & - & Jim.moreland@solarworld-usa.com \\
\hline SRI International & Eric Pearson & $\begin{array}{l}\text { Vice President, Physical } \\
\text { Sciences Division }\end{array}$ & $\begin{array}{l}333 \text { Ravenswood } \\
\text { Avenue }\end{array}$ & Menlo Park & $\mathrm{CA}$ & $94025-3493$ & $650-859-3072$ & eric.pearson@sri.com \\
\hline Underwriters Laboratory & Claire A. Kammer & Manager, Government Affairs & \begin{tabular}{|l|}
1850 M Street, Suite \\
1000
\end{tabular} & Washington & DC & 20036-5833 & $202-286-8092$ & claire.a.kammer@us.ul.com \\
\hline United Solar Ovonics & Dr. Subhendu Guha & - & 3800 Lapeer Road & Auburn Hills & $\mathrm{MI}$ & 48326 & $248-364-5709$ & sguha@uni-solar.com \\
\hline Veeco Instruments & Jeff Hohn & $\begin{array}{l}\text { Vice President Business } \\
\text { Development }\end{array}$ & \begin{tabular}{|l|} 
Veeco Instruments \\
Inc., Terminal Drive \\
\end{tabular} & Plainview & NY & & $\begin{array}{c}516-677-0200 \text { ext. } \\
1073\end{array}$ & jhohn@veeco.com \\
\hline William DeMarco & Bill DeMarco & - & 901 Ponderosa Dr. & Fort Collins & $\mathrm{CO}$ & 80521 & $585-230-7372$ & william.demarco@gmail.com \\
\hline Dow Corning & Rebecca S. Lauer & - & $\begin{array}{l}2200 \text { W. Salzburg } \\
\text { Rd. } \\
\text { P.O. Box } 994\end{array}$ & Midland & MI & 48686-0994 & $989-496-5222$ & becky.lauer@dowcorning.com \\
\hline Focus Materials & Nick Bagatelos & & 2750 Redding Ave & Sacramento & $\mathrm{CA}$ & 95820 & $916-364-3600$ & nbagatelos@bagatelos.com \\
\hline IBM & Kevin J. Hutchings & Vice President, Alliances & & $\begin{array}{c}\begin{array}{c}\text { Hopewell } \\
\text { Junction }\end{array} \\
\end{array}$ & NY & 12533 & $845-892-5265$ & kevinh@us.ibm.com \\
\hline FlexTech Alliance & Michael Ciesinski & CEO & 3081 Zanker Road & San Jose & $\mathrm{CA}$ & 95134 & $408-993-8111$ & michael.ciesinski@flextech.org \\
\hline Linde LLC, & Richard Hogle & Technical Fellow & 1970 Diamond St & San Marcos & $\mathrm{CA}$ & 92078 & $760-471-3456$ & rich.hogle@linde.com \\
\hline $\begin{array}{r}\text { Koch Solar Consultancy } \\
\text { (KoSolCo GmbH) }\end{array}$ & Dr. Wolfgang Koch & - & - & - & - & - & - & w.koch@kosolco.de \\
\hline Universitat Konstanz, & Giso Hahn & - & - & - & - & - & - & Giso.Hahn@uni-konstanz.de \\
\hline
\end{tabular}




\begin{tabular}{|c|c|c|c|c|c|c|c|c|}
\hline \multicolumn{9}{|c|}{ University Respondent Contact Information } \\
\hline Respondent & Contact & Contact Title & Street Address & City & State & Zip & Phone Number & Email \\
\hline ASU & Stuart Bowden & - & 7700 S River Pkwy & Tempe & $\mathrm{AZ}$ & 85284 & $480-727-9162$ & sgbowden@asu.edu \\
\hline \multirow{2}{*}{ ASU Flexible Display } & Nick Colaneri & Center Director & 7700 S. River Parkway & Tempe & $\mathrm{AZ}$ & 85284 & $480-727-8971$ & Nick.Colaneri@asu.edu \\
\hline & alt: Doug Loy & Director of $R \& D$ & & & & & $480-727-8932$ & dloy@asu.edu \\
\hline Georgia Inst. of Tech. & Dr. Ajeet Rohatgi & - & 777 Atlantic Drive & Atlanta & GA & 30360 & $404-894-7692$ & ajeet.rohatgi@ece.gatech.edu \\
\hline \multirow{2}{*}{ Georgia Tech } & Steven Danyluk & Professor & 813 Ferst Drive, N.W. & Atlanta & GA & 30332 & $404-894-9100$ & steven.danyluk@marc.gatech.edu \\
\hline & alt: Shreyes Melkote & Professor & & & & & 404-894-8499 & smelkote@gatech.edu \\
\hline MIT & Tonio Buonassisi & Professor & $\begin{array}{l}77 \text { Massachusetts Ave., } \\
35-213\end{array}$ & Cambridge & MS & 02139 & - & buonassisi@mit.edu \\
\hline \multirow[t]{2}{*}{ Oregon State University } & Brian Paul & Professor & - & Corvallis & OR & 97331-4501 & $541-737-7320$ & Brian.Paul@oregonstate.edu \\
\hline & alt: Skip Rung & $\begin{array}{l}\text { Pres and Exec Dir, Oregon } \\
\text { Nanoscience \& } \\
\text { Microtechnologies }\end{array}$ & P.O. Box 2041 & Corvallis & OR & 97339 & $541-713-1348$ & skip@onami.us \\
\hline South Dakota University & Dr. Shawn Decker & Director & 501 East Saint Joseph St. & Rapid City & SD & 57701 & $605-394-5210$ & Shawn.Decker@sdsmt.edu \\
\hline \multirow[t]{3}{*}{ Univ. of Albany, SUNY } & Dr. Pradeep Haldar & - & 257 Fuller Road & Albany & NY & 12203 & $518-437-8684$ & phaldar@uamail.albany.edu \\
\hline & alt: Michael Fancher & - & & & & & $518-437-8670$ & mfancher@uamail.albany.edu \\
\hline & alt: Alain Diebold & - & & & & & $518-437-8685$ & adiebold@uamail.albany.edu \\
\hline Univ. of Delaware, IEC & Robert Birkmire & Director & 106D IEC Building & Newark & $\mathrm{DE}$ & 19716 & $302-831-6220$ & rwb@udel.edu \\
\hline \multirow[t]{2}{*}{ Univ. of Michigan } & Dennis N. Assanis & Director & $\begin{array}{l}\text { 2609 Draper } \\
\text { 2nd Floor Engineering } \\
\text { Programs Building }\end{array}$ & Ann Arbor & $\mathrm{MI}$ & $48109-2101$ & $734-763-7401$ & assanis@umich.edu \\
\hline & alt: Arthur F. Thurnau & Professor & & & & & & \\
\hline Univ. of South Florida & Chris S. Ferekides & Professor & 4202 E. Fowler Ave & Tampa & $\mathrm{FL}$ & 33620 & $813-974-4818$ & ferekide@eng.usf.edu \\
\hline Univ. of Toledo & Frank J. Calzonetti & $\begin{array}{l}\text { VP for Research and } \\
\text { Economic Development }\end{array}$ & 2801 Bancroft Street & Toledo & $\mathrm{OH}$ & 43606 & 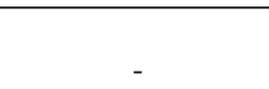 & FCalzon@UTNet.UToledo.Edu \\
\hline NC State & George Rozgonyi & Professor & & Raleigh & $\mathrm{NC}$ & $07695-7907$ & 919-515-2934 & rozgonyi@ncsu.edu \\
\hline
\end{tabular}




\begin{tabular}{|c|c|c|c|c|c|c|c|c|}
\hline \multicolumn{9}{|c|}{ Consortia Respondent Contact Information } \\
\hline Respondent & Contact & Contact Title & Street Address & City & State & Zip & Phone Number & Email \\
\hline Fraunhofer CSE & Ryan Williams & Director of Research Development & 25 First Street, Suite 101 & Cambridge & MA & 02141 & $617-757-7260$ & rwilliams@fraunhofer.org \\
\hline SEMI North America & Dan Martin & EVP for Photovoltaics & 3081 Zanker Road & San Jose & $\mathrm{CA}$ & 95134 & $408-943-7030$ & dmartin@semi.org \\
\hline Standards Tech. Group & Rick Sokoloff & VP Business Development & P.O. Box 1525 & Williston & VT & 05495 & - & rsokoloff@standardstech.com \\
\hline SVT Assoc. & Peter Chow, Ph.D. & - & 7620 Executive Drive & Eden Prairie & $\mathrm{MN}$ & 55344 & $952-934-2100$ & chow@svta.com \\
\hline SVTC Technologies & Stephen Empedocles, PhD & - & 3833 N. 1st St & San Jose & $\mathrm{CA}$ & 95134 & $650-776-7089$ & Steve.empedocles@svtc.com \\
\hline Clean Energy Group & Lewis Milford & President & 50 State street & Montpelier & $\mathrm{VT}$ & 05602 & $802-223-2554$ & Imilford@cleanegroup.org \\
\hline Natl. Center for Manf. Sci. (NCMS) & Chuck Ryan & Vice President, Technology & 3025 Boardwalk Dr. & Ann Arbor & $\mathrm{MI}$ & 48108 & $734-995-4905$ & chuckr@ncms.org \\
\hline SEMATECH & Dan Holladay & & 2706 Montopolis Drive & Austin & $T X$ & 78741 & $512-356-7139$ & Dan.Holladay@sematech.org \\
\hline SRC & Bob Havemann & & & & & & & Bob.Havemann@src.org \\
\hline The Solar Energy Consortium & Wendy Arienzo & $\begin{array}{l}\text { Research, Development and } \\
\text { Engineering }\end{array}$ & 434 Old Neighborhood Rd & Kingston & NY & & 203-470-0761 & wendy.tsec@gmail.com \\
\hline
\end{tabular}

\begin{tabular}{|r|l|l|l|c|c|c|c|c|}
\hline \multicolumn{9}{|c|}{ National Lab Respondent Contact Information } \\
\hline Respondent & Contact & Contact Title & Street Address & City & State & Zip & Phone Number & Email \\
\hline NREL Ryne Raffaelle & - & 1617 Cole Blvd., MS 3221 & Golden & Co & 80401 & $303-384-7950$ & ryne.raffaelle@nrel.gov \\
\hline PNNL Daniel R Palo & - & P.o. Box 999 & Richland & WA & 99352 & $541-713-1329$ & dan.palo@pnl.gov \\
\hline Sandia Jeff Nelson & - & - & - & - & - & - & jsnelso@sandia.gov \\
\hline
\end{tabular}


EERE Information Center 1-877-EERE-INF (1-877-337-3463)

www.eere.energy.gov/informationcenter

U.S. DEPARTMENT OF Energy Efficiency \& ENERGY Renewable Energy 